\title{
Historical and Cultural Prerequisites for the Decline of the Significance of Truth: Cujus Regio, Ejus Religio?
}

\author{
Mykolas P. Deikus ${ }^{1}$ \\ ${ }^{1}$ Department of Theology, Faculty of Catholic Theology, Vytautas Magnus University, Kaunas, Lithuania \\ Correspondence: Mykolas P. Deikus, Department of Theology, Faculty of Catholic Theology, Vytautas Magnus \\ University, Kaunas, Lithuania
}

Received: August 6, 2017

Accepted: September 19, 2017

Online Published: September 20, 2017

doi:10.5430/bmr.v6n3p58

URL: https://doi.org/10.5430/bmr.v6n3p58

\begin{abstract}
Background: This article deals with the historical and cultural prerequisites for the decline of significance of truth in Western societies. In response to the formulated problem question, the ideas taught in the disciplines of humanities and social sciences are briefly discussed, the existing conditions of the power to form the directive regime of truth in the context are outlined.

Objectives: The aim of the paper is to analyze historical and cultural prerequisites for the decline of the meaning of the truth in the public discourse.

Method: This article is prepared using the methods of analysis and synthesis of academic literature. The analysis of academic sources and the citation follows the chronology according to the publishing year of the source. The methods of comparison and analogy are also used, the authors' insights and generalizations are provided.

Conclusion: The main conclusion is formulated that culture, as shown by the history, has some self-regulatory mechanisms that occur in different forms as a significant condition, which prevents the establishment of a unidirectional regime of the truth.
\end{abstract}

Keywords: Culture, Values, Truth, Reality, Hyperreality, Corporate social responsibility

\section{Introduction}

Relevance and problem of the research. Organizations, both public and private, communicating about their activities usually face the questions of how much information to present, and what its relation to objective reality is. In this case, there are certain differences revealed between legal responsibility and moral responsibility, which is more highlighted in the context of corporate social responsibility (CSR), and becomes a difficult challenge in a competitive environment, characterised by moral duality. In the studies which examine the public image, this problem is quite often partly bypassed or certain compromises are offered hoping for growth prospects, as a certain stimulus to achieve declared values (Christensen et al., 2013). However, where is the guarantee that dishonesty in respect of the truth will evolve into integrity? The issues of the truth, as far as the written sources are known, have been ardently discussed from the times of Hellenic civilization. According to the ancient Latins, cujus regio, ejus religio (whose realm, his religion). Observing the public discourse of the $20^{\text {th }}-21^{\text {st }}$ century can give the impression that the question of confrontation of the truth and untruth has reached a peak, when mass media instruments have gained the distinctive power in the public context. Recently, it is attempted to understand the rhetoric of both the United Kingdom's withdrawal from the European Union, and D. Trump's campaigns, where the problems of public statements of truth/untruth are highlighted extremely radically (Suiter, 2016). The author analysing the processes that occur in the USA, the United Kingdom, France, and also in Eastern Europe, noticed that political ethics rules previously in force no longer work. Advertising carried out by a thriving propaganda, radical European political movements, as well as commercial structures, public relations strategies in the general information stream only highlight this problem, and the usual limits of ethical standards become blurred and easy to change by communication strategists. Truth in the public discourse has acquired the instrumental character, when the facts or manipulating them becomes a means of the power to influence the public opinion. Cultural values and norms often change over time (Giddens, 2009) and, according to Foucault (1980), each society has its regime of truth, its general politics of truth. In this context, it is important what reasons determine the interpretation of a fact, and how it is reflected in the cultural context. In addition, it is important to consider the reasons of why the organizations tend to 
adapt to the norms of a particular society. This is relevant for both new organizations starting their activities and shaping their integrity policies, and those already operating in response to changes in societies and planning the perspective. Thus, the problem question is raised - (1) what are the conditions of the mentioned truth regime and its change, and what can be the starting point of the solution of this problem? (2) how do value attitudes existing in the society influence organizational policies in respect of the truth?

The purpose of the research is to analyze historical and cultural prerequisites for the decline of the meaning of the truth in the public discourse.

Methods of the research. The article is prepared using the methods of analysis and synthesis of academic literature. The analysis of academic sources and the citation follows the chronology according to the publishing year of the source. The methods of comparison and analogy are also used, the authors' insights and generalizations are provided.

\section{Results of the Research}

Reflecting on the development of the thought of the Western civilization and the analysis of recent trends highlights the presumption that the regime of the truth as a value in the society cannot be compared with the one-way traffic in accordance with the predetermined route. On the one hand, it is quite a complicated task to evaluate how the meaning of truth as a value changed in the historic perspective in general, since there the problem of a reference point arises. Statistical research, public opinion polls are a relatively young sociological area, and various texts written a few centuries ago include reflections of the time resulting from more or less subjective position. On the other hand, it is possible to observe some trends. In addition, it would be wrong to state that this is a new problem, the problem of modern or post-modern times. The realities of truth, lies, justice, and injustice in Europe are widely discussed from the times of Ancient poleis, mostly inseparably from moral and ethics. Controversy of the truth as the unchanging idea, and the truth as a persuasion was already relevant in Socrates' polemics with sophists, who developed utilitarian ethics, as well as in the ethics of stoics, where the truth and justice, according to Marcus Aurelius (2012), is one of the principles of the "social" man, the citizen outlining the good.

According to Baranova (2002), the belief that the truth is a match of the idea (the subjective image in our mind) and the thing (something beyond the mind), (in which the medieval theologian Thomas Aquinas has introduced the platonic God's clause) prevailed in the European civilization from Aristotle's times. Aristotle grounded the principles of justice as a moral virtue relevant to the society, and the common good, guaranteed by the law: "<..> we consider the actions, whose purpose is to create and maintain happiness and everything it is made of, for the whole community of citizens to be just" (Aristotelis, 1990, p. 146). In other words, the agreement is based on the moral imperatives. But what is identified in culture as "moral" or "immoral" is determined both by the human psychology and the agreement and is volatile, therefore, in the $18^{\text {th }}$ century Kant (1999) proposed the principle of categorical imperative and considered the mind to be the essential starting point, what should be sort of protection from the impact of these variables. After a while, Mill (1871), defending the opportunities of utilitarian agreement, although admiring Kant, argued to the contrary, again, idealistically claiming that with the development of civilisation the possibilities of compassion and reasonable agreement increase, so each step on the path of political improvement helps to avoid contraposition of interests by eliminating various unequal legal privileges. According to Mill (1871), the development of the mind, the perception of the common good and unity serves as something what the "religion did formerly". Thus, there should "be more" truth, but both Kantian and Mill's idealism are negated by genocide and various authoritarian regimes.

The value basis and the attitude towards what the truth is, is provided by culture, which, according to Myers (2012) conveys the long-term models of behaviour, ideas, attitudes and traditions, is not static. For example, Held (2006) conveys the marxist approach to evolution of the society and its culture in the course of history, according to which, choice opportunities of each new generation are partly "inherited", that is determined by the efforts of previous generations. These efforts to "construct" the society and its values occur both in ancient (e.g., Plato's "Republic") philosophic-social systems and later ideologies. For example, according to Bauman (2015, p. 66), in the opinion of pioneers of the Enlightenment, the rules implemented by the tradition have become an obstacle rather than help for the whole life, believing that their aim is to "arrange the society". Later this accompanied the decline of traditional communities and strengthening of the individualism and has become a strong impulse for modern culture of society and its values. These tendencies are typical of not only Europe. For instance, Giddens (2009) discusses the opinion of the contemporary government of Japan, which declares that Japan would successfully overcome social problems, if "the citizens of the country less complied with some of their fundamental values" (p. 39). The author questions whether the values will change easily by the order of the government. However, the consequences of another, communist experiment, carried out in Eastern Europe, even after the collapse of the regimes de jure, had an 
irreversible impact on the values of the liberated societies (Tismaneanu, 2009). In this context, some authors also distinguish the role of the authority and religion. Fromm (2013) drew attention to the differences in the meaning of the authority in different societies. For example, in the primitive society, only the authority is the most competent to carry out a task. In the patriarchal society the object of the authority is a woman, and in bureaucratic, hierarchically organised society everyone, with the exception of the lowest social layer, can be the authority. It must be recognised that hierarchical structures in post-communist societies have transformed, outgrowing from the institutional role into the sources of corporate power, mixed with pop-culture, dictating the rules of the game of the new elite.

Both the Western and the Eastern European culture for many centuries developed on the basis of moral and ethics formed by Hellenistic philosophy and Christianity, supported by the religious authority. According to Žiliukaite et al. (2016), who researched the values of the post-communist society, the change of values in traditional societies is inseparable from the change of religious values, as well as the "place" of the religion in the social structure. And the influence of the latter in social structure is rapidly declining in the $20^{\text {th }}-21^{\text {st }}$ centuries. In our times, the time has come for the society (this mysterious and incognizable "imaginary being", which by the decree of the modern spirit had to replace God, taking over his function to take over and administer human affairs) to admit that a person has sufficient powers to deal with them alone and give up prescribing (Bauman, 2015, p. 72-73). Having questioned the cultural tradition in this way and the transferred the decision power on an individual's freedom scale, the fundamental basis of values, which becomes sensitively ductile to the sources of information power, is eliminated. Not coincidentally, Suiter (2016) is trying to look at the changes in Western societies from the perspective of the latter half a hundred years, relating with the changes of liberal economics, democratic processes, education of a great part of the of electorate and their reactions to the ongoing processes (e.g., migration). On the other hand, although, compared to the previous centuries, both the level of education and economic well-being of Western states have increased incomparably, but the subjectively perceived dimension of personal safety remains little altered, thus, the politics often focuses on the highlighting of worrying phenomena (e.g. migration). In this context, the role of interest is significant. For instance, Coleman (1994), discussing various social theories, speaks about the role of the control of interests and resources. According to the author, within a couple of centuries interest has been transformed from euphemistic descriptions to more open forms. Machiavelli's advice for a ruler, which led to the development of the idea of ruling the state free from any moral standards, are presented as one of the classic examples of the dominance of interest. The more so as the regime of individualistic values Myers (2012) called caring for what is "best for me" has occurred in the course of the history in the Western culture. In this context, not only the collective memory gaps are relevant, but also the influence of the image created by a person, the media on voters' decisions (Street, 2004; Hyun, Moon, 2014; Bakiner, 2015; etc.). Furthermore politicians use social media and personalization to circumvent mainstream news media, disrupting conventional processes. This personalization arguably increases voters' reliance on personal characteristics as voting heuristics (McGregor, 2017). It is not coincidence that J. Baudrillard (1985) speaks about the simulated reality, which has neither the origin nor the reality, which could be called a hyperreality, i.e. the reality that has existed for centuries, but most highlighted during the postmodern era, at the time of an increasing media dominance. In other words, the Aristotelian principle of truth, as a match of the "thing" and its "essence" loses the previous functionality, as the user's relationship with the reality is decreasing in the stream of flooding news, which the user has less opportunities to "check" and there remains more or less possibility of "trust". Therefore, according to Rubavičius (2010), popular culture and mass-media industry extends the opportunities to construct the proper user, life styles, beliefs and attitudes (p. 20). It fosters organizations to invest in the development of the brand as virtual reality. But here we face a certain possibility of fiction of the truth, even in the cases when organizations demonstrate high standards of CSR. The use of these standards can be thought of in the context of the development of the company's brand (Bhattacharya, Kaursar, 2016), especially as an instrument to increase the attractiveness and income (Cha et al., 2015). At the same time, because of giving prominence to CSR, there is a risk for the brand of the enterprise that due to internal and external reasons this strategy becomes dominant, using social responsibility rather as a marketing strategy, leaving actual values in the background (Vveinhardt, Sonkute, 2015, p. 16). In this dynamic environment, the studies of trends within operating organizations can be divided into several conditional groups according to the highlighted problems and the outlined prospects: orientation towards the public values (adapting to the changing public expectations); CSR ideals formed by organizational values (shaped on the basis of moral values); turning back to the moral, based on the tradition of faith. The trends are summarised in the table. 
Table 1. Attitudes and prospects

\begin{tabular}{|c|c|c|c|}
\hline Attitudes & Sources & Idea & Prospects \\
\hline $\begin{array}{l}\text { Flexible adaptation to } \\
\text { trends in public values }\end{array}$ & $\begin{array}{l}\text { M. Vashchenko (2017); } \\
\text { C. L. White et al. } \\
\text { (2017); Y. Lu and I. } \\
\text { Abeysekera (2017); L. } \\
\text { Laidroo and U. Ööbik, } \\
\text { (2013); et al. }\end{array}$ & $\begin{array}{l}\text { Organizations respond } \\
\text { flexibly, taking into } \\
\text { account the expectations } \\
\text { and pressure in a } \\
\text { particular society }\end{array}$ & $\begin{array}{l}\text { Organizations operate in a flexible } \\
\text { manner. Public values are } \\
\text { highlighted as a variable and } \\
\text { alterable component. This is the } \\
\text { most difficult component to define } \\
\text { because of the duality and dynamics. } \\
\text { There is a danger of moral duplicity } \\
\text { when different standards are applied } \\
\text { in socio-cultural environments. }\end{array}$ \\
\hline $\begin{array}{l}\text { Construction of } \\
\text { universal CSR values }\end{array}$ & $\begin{array}{l}\text { U. R. Richter and K. E. } \\
\text { Dow (2017); L. } \\
\text { Corazza (2017); T. Jain } \\
\text { (2017), J. Vveinhardt } \\
\text { and E. Stonkute } \\
\text { (2015); et al. }\end{array}$ & $\begin{array}{l}\text { Certain universal fair } \\
\text { play rules declared by } \\
\text { companies, based on the } \\
\text { unwritten agreement with } \\
\text { stakeholders }\end{array}$ & $\begin{array}{l}\text { Develop standards for responsible } \\
\text { performance. The values declared by } \\
\text { the organization become a certain } \\
\text { social contract with the } \\
\text { commitment, the implementation of } \\
\text { which is controlled to a certain } \\
\text { extent by stakeholders. Conformity } \\
\text { of the declared values with the } \\
\text { reality depends on the stakeholders' } \\
\text { consciousness and civic activity. } \\
\text { When there is the lack of internal } \\
\text { moral imperatives, the risk of CSR } \\
\text { turning into a marketing instrument } \\
\text { arises. A variety of standards and } \\
\text { uncertainty. }\end{array}$ \\
\hline $\begin{array}{l}\text { The values derived } \\
\text { from the traditional } \\
\text { religious belief }\end{array}$ & $\begin{array}{l}\text { J. Cui et al. (2017); } \\
\text { C. M. V. D. D. } \\
\text { Schouten et al. (2014); } \\
\text { B. Muniapan and B. } \\
\text { Satpathy (2013); et al. }\end{array}$ & $\begin{array}{l}\text { The commitment based } \\
\text { on religious and moral } \\
\text { system of values }\end{array}$ & $\begin{array}{l}\text { Specifically defined universal values } \\
\text { derived from personal moral } \\
\text { commitment, determining the } \\
\text { integrity of values in activities of the } \\
\text { organization. High moral standards, } \\
\text { high risk of losses in breach of them. }\end{array}$ \\
\hline
\end{tabular}

The problem of truth in both the public and private sector organizations is emerging as an issue of radical fairness in relations with everyone in one way or another affected by the activities of the organization. In this case, the question arises not because of how much the organization is fair in its internal and public activities, but whether it is fair at all. At the same time, there inevitably raises the question of the extent to which it is worth to the organization be honest in the environment that tolerates double moral standards.

The logic of competitiveness presupposes a certain moral compromise, which to a lesser or greater extent is chosen by both organizations declaring CSR and not declaring it. Does this mean that the significance of truth in public discourse tends to experience the full failure? However, the answer is not unambiguous. Analysts dealing with the trends of historical and cultural evolution of the society state, but underestimate the fact that these processes are not unidirectional. On the one hand, the historical evolution of culture gives the person the power of the decision about the truth and its value, on the other hand, this burden is not psychologically easy. Can a labile new pop-political culture take over this burden of decision? The answers may be looked for in the trends that take place in societies. On the one hand, orientation of both the USA and the European radical politicians towards conservative ideas can be seen as a certain reaction to the climate of opinion. The studies and forecasts of the trends of recent decades in the world show that Catholic population of the African continent will increase up to $49.3 \%$ by 2020 , the growth tendencies are visible in the Asian continent, Europe, and in South America Christians will continue to be an absolute majority. It is predicted that the Christian population in North America and Europe will account for about $80 \%$ of the total population (Johnson et al., 2013). On the other hand, business responds in the most sensitive way by constructing socially responsible relationship with the consumers based on traditional values in different countries (Whelan, 2007; Muniapan, Satpathy, 2013; Dhanesh, 2014; Mostafa, ElSahn, 2016; Campos, 2017; etc.). This shows 
that in spite of the idea of the liberal society developed from the French revolution and the secular politics of the state, the tendency to return to conservative values relevant to a traditional culture is strengthening both in Europe and in other countries.

\section{Discussion}

Power, regardless of its nature, source or the historic period, tends to set the rules of the game based on self-preservation and this corresponds to the truth regime. However, this regime could not be equated to the fatalistic one-way traffic, as culture, as it is shown by the history, has some dynamic self-regulatory mechanisms. The regime of the truth as a value in the society is not unidirectional. Several historical and cultural prerequisites of the decrease of the significance of truth can be distinguished. Although it may seem paradoxical, but in Western culture, which is based on the Aristotelian definition of the truth for a few centuries, the truth is losing the adequacy of connection and the reality, that becomes subject to interpretation when moral values are changing. Looking from historical perspective, perception of the truth as a value in Western culture is inseparable from the structures supporting the values, one of which is religion, the influence of which began to weaken significantly under the influence of the ideas of the Renaissance and the Enlightenment. This is related to the utilitarian worldview and the opportunities for the emergence of individual interest, the power of which is redistributed and the number of economically strong power centres is increasing with the modernising society. With the increasing flow of information, the consumers' psychological opportunities to process it do not change, therefore, the role of trust, transforming into persuasion, converting relationship with reality into the hyperreality construct, is increasing. Historical examples show efforts to shape the culture on the basis of the interest-based system. The more so as the expanding media industry is becoming one of significant players of the power to develop interests, shape the user, form attitudes and values. However, in this context, the need of the public to return to the fundamental constructs is highlighted, where the issue of truth is highlighted by a new problem when using these trends the corporate-political structures use the destroyed system of values. Anyway, the return of the society to religion and traditional values is a sign, fostering responsibility towards organizations declaring stakeholders to review their policy of values. Universal values derived from personal moral commitment defined in this aspect determine integrity of values in activities of the organization.

\section{References}

Aristotelis (1990). Rinktiniai raštai. Vilnius: Mintis. 479 p. ISBN: 5417001589 [Aristotle. Selected Works, in Lithuanian].

Bakiner, O. (2015). One truth among others? Truth commissions' struggle for truth and memory. Memory Studies, 8(3), 345-360. https://doi.org/10.1177/1750698014568245

Baranova, J. (2002). Pragmatizmo recepcija postfilosofijoje. Problemos, 62, 128-137. [Reception of Pragmatism in Postphilosophy, in Lithuanian].

Baudrillard, J. (1985). Simulacres et simulation. Paris: Editions Galilée. 233 p. ISBN-10: 2718602104

Bauman, Z. (2015). Kultūra takiojoje modernybeje. Vilnius: Apostrofa. 160 p. ISBN 9789955605591 [Culture in a Liquid Modern World, in Lithuanian].

Bhattacharya, S., \& Kaursar, A. (2016). Study on Corporate Social Responsibility as Strategic Instrument for Creating Sustainable Corporate Brand Value: An Analysis with Structural Equation Modelling. Management and Labour Studies, 41(2), 88-106. https://doi.org/10.1177/0258042X16658727

Campos, C. (2017). Laudato Si': An Indian Perspective. Theological Studies, 78(1), 213-225. https://doi.org/10.1177/0040563916682428

Cha, M.-K., Yi, Y., \& Bagozzi, R. P. (2015). Effects of Customer Participation in Corporate Social Responsibility (CSR) Programs on the CSR-Brand Fit and Brand Loyalty. Cornell Hospitality Quarterly, 57(3), 235-249. https://doi.org/10.1177/1938965515620679

Christensen, L. T., Morsing, M., \& Thyssen, O. (2013). CSR as aspirational talk. Organization, 20(3), 372-393. https://doi.org/10.1177/1350508413478310

Coleman, J. S. (1994). Foundations of Social Theory. Belnap Press. 1014 p. ISBN-10: 0674312260

Corazza, L., Scagnelli, S. D., \& Mio, C. (2017). Simulacra and Sustainability Disclosure: Analysis of the Interpretative Models of Creating Shared Value. Corporate Social Responsibility and Environmental Management, 24(5), 414-434. https://doi.org/10.1002/csr.1417

Cui, J., Jo, H., \& Na, H. (2017). Corporate Social Responsibility, Religion, and Firm Risk. Asia-Pacific Journal of 
Financial Studies, 46(2), 305-340. https://doi.org/10.1111/ajfs.12171

Dhanesh, G. S. (2014). Why corporate social responsibility? An analysis of drivers of CSR in India. Management Communication Quarterly, 29(1), 114-129. https://doi.org/10.1177/0893318914545496

Foucault, M. (1972). The Archaeology of Knowledge. The Discourse on Language. New York: Pantheon Books. 246 p.

Foucault, M. (1980). Truth and Power. In C. Gordon (ed.). Power/Knowledge: Selected Interviews and Other Writings 1972-1977. New York: Pantheon Books. 109-133.

Fromm, E. (2013). To Have or to Be? Bloomsbury Academic. 216 p. ISBN-10: 178093680X

Giddens, A. (2009). Sociology. 6th Edition. Polity Press. 1000 p. ISBN-10: 0745643582

Held, D. (2006). Models of Democracy. 3rd Revised Edition. Polity Press. 408 p. ISBN-10: 0745631479

Hyun, K. D., \& Moon, S. J. (2014). News Media's Role in the Issue-Voting Process: News Attention, Issue Proximity, and Vote Choice. Journalism \& Mass Communication Quarterly, 91(4), 687-705. https://doi.org/10.1177/1077699014550095

Jain, T. (2017). Decoupling Corporate Social Orientations: A Cross-National Anglysis. Business \& Society, 56(7), 1033-1067. https://doi.org/10.1177/0007650315610609

Kant, I. (1999). Critique of Pure Reason (The Cambridge Edition of the Works of Immanuel Kant). Cambridge University Press. 796 p. ISBN-10: 0521657296

Laidroo, L., \& Ööbik, U. (2013). Banks' CSR disclosures - headquarters versus subsidiarines. Baltic Journal of Management, 9(1), 47-70. https://doi.org/10.1108/BJM-05-2013-0091

Lu, Y., \& Abeysekera, I. (2017). What Do Stakeholders Care About? Investigating Corporate Social and Environmental Disclosure in China. Journal of Business Ethics, 144(1), 169-184. https://doi.org/10.1007/s10551-015-2844-5

Marcus Aurelius (2012). Meditations. CreateSpace Independent Publishing Platform. 128 p. ISBN-10: 1470089734

McGregor, S. C. (2017). Personalization, social media, and voting: Effects of candidate self-personalization on vote intention. New Media \& Society. https://doi.org/10.1177/1461444816686103

Mill, J. S. (1871). Utilitarianism. 4th Edition. London: Longmans, Green, Reader, and Dyer. 96 p.

Mostafa, R. B., \& ElSahn, F. (2016). Exploring the mechanism of consumer responses to CSR activities of Islamic banks: the mediating role of Islamic ethics fit. International Journal of Bank Marketing, 34(6), 940-962. https://doi.org/10.1108/IJBM-11-2015-0179

Muniapan, B., \& Satpathy, B. (2013). The 'Dharma' and 'Karma' of CSR from the Bhagavad-Gita. Journal of Human Values, 19(2), 173-187. https://doi.org/10.1177/0971685813492265

Myers, D. G. (2012). Social Psychology. 11th Edition. McGraw-Hill Education. 768 p. ISBN-10: 0078035295

Richter, U. R., \& Dow, K. E. (2017). Stakeholder theory: A deliberative perspective. Business Ethics-A European Review, 26(4), 428-442. https://doi.org/10.1111/beer.12164

Rubavičius, V. (2010). Postmodernusis kapitalizmas: monografija. Kaunas: Kitos knygos. 269 p. ISBN 978-609-427-000-0 [Postmodern Capitalism: Monograph, in Lithuanian].

Schouten, C. M. V. D. D., Graafland, J., \& Kaptein, M. (2014). Religiosity, CSR Attitudes, and CSR Behavior: An Empirical Study of Executives' Religiosity and CSR. Journal of Business Ethics, 123(3), 437-459. https://doi.org/10.1007/s10551-013-1847-3

Street, J. (2004). Celebrity Politicians: Popular Culture and Political Representation. The British Journal of Politics and International Relations, 6(4), 435-452. https://doi.org/10.1111/j.1467-856X.2004.00149.x

Suiter, J. (2016). Post-Truth Politics. Political Insight, 7(3), 25-27. https://doi.org/10.1177/2041905816680417

Tismaneanu, V. (2009). Fantasies of Salvation: Democracy, Nationalism, and Myth in Post-Communist Europe. Princeton University Press. 256 p. ISBN-10: 0691144389. https://doi.org/10.1515/9781400822508

Vashchenko, M. (2017). An external perspective on CSR: What matters and what does not? Business Ethics-A European Review, 26(4), 396-412. https://doi.org/10.1111/beer.12162

Whelan, G. (2007). Corporate social responsibility in Asia: a Confucian context. In S. May, G. Cheney, \& J. Roper 
(Eds.). The Debate over Corporate Social Responsibility. New York, NY: Oxford University Press. 105-118. 490 p. ISBN 978-0-19-517882-1

White, C. L., Nielsen, A. E., \& Valentini, C. (2017). CSR research in the apparel industry: A quantitative and qualitative review of existing literature. Corporate Social Responsibility and Environmental Management, 24(5), 382-394. https://doi.org/10.1002/csr.1413

Vveinhardt, J., \& Stonkute, E. (2015). Corporate Social Responsibility as a Brand: Practical Activity or Social Hypocrisy? International Conference on Marketing and Business Development Journal, 1(1), 9-20. Article published online: http://www.mbd.ase.ro/RePEc/aes/icmbdj/2015/ICMBDJ_V1_2015_12.pdf

Žiliukaitė, R., Poviliūnas, A., \& Savicka, A. (2016). Lietuvos visuomenès vertybiu kaita per dvidešimt nepriklausomybès metu: monografija. Vilnius. Vilniaus universiteto leidykla. 316 p. ISBN 978-609-459-737-4 [The change of the Values of the Lithuanian Society During Twenty Years of Independence: Monograph, in Lithuanian]. 